\title{
Comparative study of sickle cell anemia and hemoglobin SC disease: clinical characterization, laboratory biomarkers and genetic profiles
}

Milena Magalhães Aleluia ${ }^{1,2}$, Teresa Cristina Cardoso Fonseca ${ }^{3,4}$, Regiana Quinto Souza ${ }^{3,4}$, Fábia Idalina Neves ${ }^{3}$, Caroline Conceição da Guarda 1,2, Rayra Pereira Santiago 1,2, Bruna Laís Almeida Cunha², Camylla Villas Boas Figueiredo ${ }^{1,2}$, Sânzio Silva Santana ${ }^{1,2}$, Silvana Sousa da Paz ${ }^{1}$, Júnia Raquel Dutra Ferreira ${ }^{1,2}$, Bruno Antônio Veloso Cerqueira ${ }^{5}$ and Marilda de Souza Gonçalves ${ }^{1,2^{*}}$

\begin{abstract}
Background: In this study, we evaluate the association of different clinical profiles, laboratory and genetic biomarkers in patients with sickle cell anemia (SCA) and hemoglobin SC disease (HbSC) in attempt to characterize the sickle cell disease (SCD) genotypes.

Methods: We conducted a cross-sectional study from 2013 to 2014 in 200 SCD individuals (141 with SCA; 59 with $\mathrm{HbSC}$ ) and analyzed demographic data to characterize the study population. In addition, we determined the association of hematological, biochemical and genetic markers including the $\beta^{\mathrm{S}}$-globin gene haplotypes and the 3.7 $\mathrm{Kb}$ deletion of a-thalassemia ( $-a^{3.7 \mathrm{~Kb}}$-thal), as well as the occurrence of clinical events in both SCD genotypes.

Results: Laboratory parameters showed a hemolytic profile associated with endothelial dysfunction in SCA individuals; however, the HbSC genotype was more associated with increased blood viscosity and inflammatory conditions. The BEN haplotype was the most frequently observed and was associated with elevated fetal hemoglobin $(\mathrm{HbF})$ and low $\mathrm{S}$ hemoglobin $(\mathrm{HbS})$. The $-\mathrm{a}^{3.7 \mathrm{~Kb}}$-thal prevalence was $0.09(9 \%)$, and it was associated with elevated hemoglobin and hematocrit concentrations. Clinical events were more frequent in SCA patients.
\end{abstract}

Conclusions: Our data emphasize the differences between SCA and HbSC patients based on laboratory parameters and the clinical and genetic profile of both genotypes.

Keywords: Sickle cell anemia, Hemoglobin SC disease, Biomarkers, Genetic profile

\section{Background}

Sickle cell disease (SCD) is a group of inherited diseases that includes sickle cell anemia (SCA), which is the homozygous state of the beta $\mathrm{S}\left(\beta^{\mathrm{S}}\right)$ allele and the most severe SCD genotype. Likewise, the heterozygous state of the $\beta^{S}$ allele is characterized by the presence of hemoglobin $\mathrm{S}(\mathrm{HbS})$ associated with changes in the

\footnotetext{
*Correspondence: mari@bahia.fiocruz.br

'Laboratório de Hematologia e Genética Computacional, Instituto Gonçalo

Moniz - IGM, Fundação Oswaldo Cruz (Fiocruz), Rua Waldemar Falcão, 121,

Candeal, Salvador, Bahia CEP 40296-710, Brazil

${ }^{2}$ Universidade Federal da Bahia (UFBA), Salvador, Bahia, Brazil

Full list of author information is available at the end of the article
}

structure or synthesis of the other globin chain and consists of a group of less severe SCD, including hemoglobin SC disease (HbSC). SCD has important implications for public health, as both worldwide incidence and prevalence are high, which reinforces it as a significant social problem in many countries $[1,2]$. The clinical diversity of SCD includes hemolytic and vaso-occlusive episodes (VOE), infections, stroke, acute chest syndrome (ACS), pulmonary hypertension, multiple organ dysfunctions and other complications [3]. Several factors have been shown to modulate the clinical manifestations of SCD including hematological, biochemical, inflammatory and genetic 
markers, as well as environmental, sociodemographic, and socioeconomic characteristics [3, 4].

With respect to the genetic markers, SCA patients can also be carriers of one or more gene determinants such as the $3.7 \mathrm{~Kb}$ deletion of $\alpha$-globin chain in $\alpha$-thalassemia $\left(-\alpha^{3.7 \mathrm{~Kb}}-\right.$ thal). In Afro-descendants, the heterozygous $(-\alpha / \alpha \alpha)$ or homozygous $(-\alpha /-\alpha)-\alpha^{3.7 \mathrm{~Kb}}$-thal genotype in SCA individuals is associated with a reduction in $\mathrm{HbS}$ concentration, which consequently lowers hemoglobin polymerization and cell damage and improves the hemolysis profile $[5,6]$. In addition, this association promotes changes in hematological and biochemical parameters of SCA [5-7].

$\beta^{S}$ globin gene haplotypes are constituted of polymorphisms in the $\beta^{S}$ globin gene cluster, which are associated with specific levels of fetal hemoglobin ( $\mathrm{HbF}$ ), contributing to phenotypic diversity in SCA patients [8-10]. There are five main haplotypes, named Benin (BEN), Central African Republic (CAR), Senegal (SEN), Arab-Indian, and Cameroon (CAM), according to their geographical origin and ethnic groups $[9,11]$.

Considering the wide range of variability in the severity of SCA and HbSC individuals, laboratory biomarkers associated to hemolysis such as reticulocyte count and serum LDH, in addition to biomarkers of blood viscosity such as hemoglobin and hematocrit concentration, are important to perform a laboratorial characterization of the patients as well as to understand the disease physiopathology [12]. HbF levels, inflammatory response and endothelial dysfunction play a pivotal role in differentiating SCD sub-phenotypes [12, 13].

The severity of SCD arises from several clinical complications that influence each individual's immunity. Therefore, the use of medication, prophylactic vaccines and practicing healthy habits are recommended $[14,15]$. However, another important point is the cost to the health care system and how much the government pays for each patient with SCD, including hospital admissions and readmissions, therapy and the spectrum of comorbidities that may require years of follow-up in different specialists $[15,16]$.

In this study, we investigated the association of different clinical manifestations, laboratory biomarkers and genetic profiles in patients with SCA and HbSC to establish parameters that highlight sub-phenotypes differences in these SCD genotypes.

\section{Methods}

\section{Subjects}

We conducted a cross-sectional study from 2013 to 2014 at the Itabuna Reference Center for Sickle Cell Disease in Itabuna, Bahia, Brazil, that develop the follow-up of 536 SCD patients from the south coast, extreme south and southwest regions of Bahia. Considering the cross-sectional nature of the study, the sample size calculation was performed on StatCalc, Epi Info, v.6.04 with a power of $95 \%$ and two-sided confidence level of $95 \%$. Thus, we identify that a sample-size of 200 individuals with SCD would be a significant representation of the population, taking account a frequency of $1 /$ 650 children with SCD in Bahia state. Our sample size was 200 SCD patients (141 with SCA and 59 with $\mathrm{HbSC}$ ) with a mean age of $16.06 \pm 11.83$ years and a median age of 13 years (range: 1-61 years). Clinical data were collected from the medical records. Each patient enrolled in the study was in a steady state, had not received a blood transfusion in the last six months and were not taking hydroxyurea (HU). Informed consent form was obtained from all adult participants as well as parents or guardians of the children also have assigned the informed consent form prior to the enrollment in the study. The study protocol was approved by the Ethics Research Board of the Gonçalo Moniz Institute of the Oswaldo Cruz Foundation (IGM-FIOCRUZ-BA) following the ethical principles of the Declaration of Helsinki of 1975 and its revision.

\section{Hematological and biochemical parameters}

Hematological analyses were carried out using Sysmex KX-21 $\mathrm{N}^{\mathrm{sm}}$ Automated Hematology Analyzer (Sysmex Corporation, Tokyo, Japan). Serum lipids and lipoproteins were analyzed using fully automated equipment (Cobas, Roche Diagnostics, Salt Lake City, Utah, USA). Hemoglobin profiles and $\mathrm{HbF}$ concentration were determined using High Performance Liquid Chromatography (HPLC, VARIANT I-Bio-Rad, CA, USA). Nitric oxide metabolites (NOm) were determined using the Griess reaction, as previously described [17].

\section{Genetic analysis}

Genomic DNA was extracted from leukocytes using a QIAamp ${ }^{\circ}$ DNA Extraction Kit (Qiagen, Hilden, Germany) following the manufacturer's instructions. $\beta^{S}$ globin gene cluster haplotypes were investigated using polymerase chain reaction (PCR) followed by restriction fragment length polymorphism (RFLP). The primers used detecting the $\beta^{S}$ globin gene cluster haplotypes are: $5^{\prime} \gamma^{G}$ gene 5'-AACTGTTGCTTTATAGGATTTT-3' and 3'-AGGAG CTTATTGATAACTCAGAC-5'; $\gamma^{\mathrm{G}} / \gamma^{\mathrm{A}}$ gene $5^{\prime}$-AAGTG TGGAGTGTGCACATGA-3' and 3 '-TGCTGCTAATGC TTCATTACAA-5 $; \gamma^{\mathrm{G}} / \gamma^{\mathrm{A}}$ gene $5^{\prime}$ - TGCTGCTAATG CTTCATTACAA-3' and $3^{\prime}$-TAAATGAGGAGCATGCA CACAC-5'; $\Psi \beta$ gene $5^{\prime}$-GAACAGAAGTTGAGATAGA GA-3' and $3^{\prime}$-ACTCAGTGGTCTTGTGGGCT-5'; $3^{\prime} \Psi \beta$ gene $5^{\prime}$-TCTGCATTTGACTCTGTTAGC-3' and 3'-GG ACCCTAACTGATATAACTA-5' $[10,18]$. Allele-specific PCR was used to investigate the $-\alpha^{3.7 \mathrm{~Kb}}$-thal deletion presence [19]. All analyses were performed in the Anemia Research Laboratory at the Federal University 
of Bahia and Laboratory of Hematology, Genetics and Computational Biology at the IGM-FIOCRUZ-BA.

\section{Statistical analysis}

Baseline values of selected variables were summarized as the mean and stratified according to percentile. Distribution of the quantitative variables was analyzed using Shapiro-Wilk test. Quantitative variables were compared between two groups using the t-test for data with a parametric distribution and the Mann-Whitney test for nonparametric data. The Chi-square test and Fisher exact test were used to analyze the qualitative or categorical variables. Statistical analyses were performed using the Statistical Package for the Social Sciences (SPSS) version 20.0 software (IBM, New York, NY, USA), and $P$ values $<0.05$ were considered significant.

\section{Results}

In our study, we analyzed patients with SCA and $\mathrm{HbSC}$ and have identified that the majority of the SCD patients were female $(52.0 \% ; 104 / 200)$ and were aged either between 6 and 10 years $(22.0 \%$; 44/200) or 21 and 30 years (20.0\%; 40/200). As recommended by the Brazilian Institute of Geography and Statistics the ethnicity was selfdeclared and the majority of patients were African derived people $(89.0 \%$; $178 / 200)$ (Table 1$)$. With respect to patients' educational level, the frequency of uneducated or partially completed elementary school was $12.0 \%$ (24/ 200 ) in the age group of 11 to 15 years old, and $8.5 \%$ $(17 / 200)$ in the age group older than 16 years old. In addition, in the age group older than 16 years old we also observed a frequency of $20.0 \%(40 / 200)$ of the patients only completed elementary school (Table 1 ). The age at first diagnosis of SCD was younger than 6 months of age in the majority of the patients (38.0\%; 76/200), and 68 patients in this group were diagnosed through the newborn screening. In addition, $25.0 \%$ of the patients were diagnosed between the age of 7 months and 4 years $(50 / 200)$ and $17.0 \%$ were diagnosed between the ages of 5 and 9 years $(34 / 200)$ (Table 1$)$. When we analyzed the number of patients who have any relatives with SCD, we found that $31.5 \%(63 / 200)$ had a sibling with the disease, and $28.5 \%(57 / 200)$ had four or more sibling with SCD (Table 1).

SCD patients were from several cities belonging to administrative regions, with $78.0 \%$ from the south coast of Bahia, 14.5\% from the extreme south of Bahia, and 7.5\% from the southwest of Bahia (Fig. 1). On the south coast, the city of Itabuna had the highest number of SCD patients, which represented $38.5 \%(77 / 200)$ of the study population, followed by Eunapólis, Ilhéus, Porto Seguro, and Camacan, which had 6.0\% (12/200), 6.0\% (12/200),

Table 1 Characterization of SCD patients followed by the Reference Center in the South of Bahia, Brazil

\begin{tabular}{|c|c|c|c|c|c|c|c|c|}
\hline Age (years) & N (\%) & Sex & N (\%) & Ethnicity & $N(\%)$ & \multicolumn{2}{|c|}{ Region of Origin } & N (\%) \\
\hline$\leq 5$ & $36(18.0)$ & Female & $104(52.0)$ & Caucasian & $13(6.5)$ & \multicolumn{2}{|c|}{ South Coast } & $156(78.0)$ \\
\hline 6 to 10 & $44(22.0)$ & Male & $96(48.0)$ & African & $178(89.0)$ & \multicolumn{2}{|c|}{ Extreme South } & $29(14.5)$ \\
\hline 11 to 15 & $37(18.5)$ & & & Asian & $9(4.5)$ & \multicolumn{2}{|c|}{ Southwest } & $15(7.5)$ \\
\hline 16 to 20 & $21(10.5)$ & & & & & & & \\
\hline 21 to 30 & $40(20.0)$ & & & & & & & \\
\hline$\geq 31$ & $22(11.0)$ & & & & & & & \\
\hline $\begin{array}{l}\text { Number of } \\
\text { siblings with SCD }\end{array}$ & $N(\%)$ & Age at 1st Diagnosis & $N(\%)$ & Relatives with SCD & N (\%) & \multicolumn{2}{|c|}{ Education (by age group) } & N (\%) \\
\hline 0 & $21(10.5)$ & $\leq 6$ months & $76(38.0)$ & None & $100(50.0)$ & \multirow[t]{2}{*}{$\leq 5$} & Uneducated or incomplete & $36(18.0)$ \\
\hline 1 & $47(23.5)$ & 7 months to 4 years & $50(25.0)$ & Father & $4(2.0)$ & & elementary school & \\
\hline 2 & $42(21.0)$ & 5 to 9 years & $34(17.0)$ & Mother & $3(1.5)$ & \multirow[t]{3}{*}{6 to 10} & Uneducated or incomplete & $34(17.0)$ \\
\hline 3 & $33(16.5)$ & 10 to 14 years & $11(5.5)$ & Brother & $63(31.5)$ & & elementary school & \\
\hline \multirow[t]{9}{*}{4 or More } & $57(28.5)$ & 15 to 17 years & $15(7.5)$ & Cousin & $22(11.0)$ & & Elementary school & $10(5.0)$ \\
\hline & & $\geq 17$ years & $14(7.0)$ & Aunt and Uncle & $1(0.5)$ & \multirow[t]{3}{*}{11 to 15} & Uneducated or incomplete & $24(12.0)$ \\
\hline & & & & Nephews & $2(1.0)$ & & elementary school & \\
\hline & & & & Not heard & $5(2.5)$ & & Elementary school & $13(6.5)$ \\
\hline & & & & Inform & & \multirow[t]{5}{*}{$\geq 16$} & Uneducated or incomplete & $17(8.5)$ \\
\hline & & & & & & & elementary school & \\
\hline & & & & & & & Elementary school & $25(12.5)$ \\
\hline & & & & & & & High School & $40(20.0)$ \\
\hline & & & & & & & University & $1(0.5)$ \\
\hline
\end{tabular}




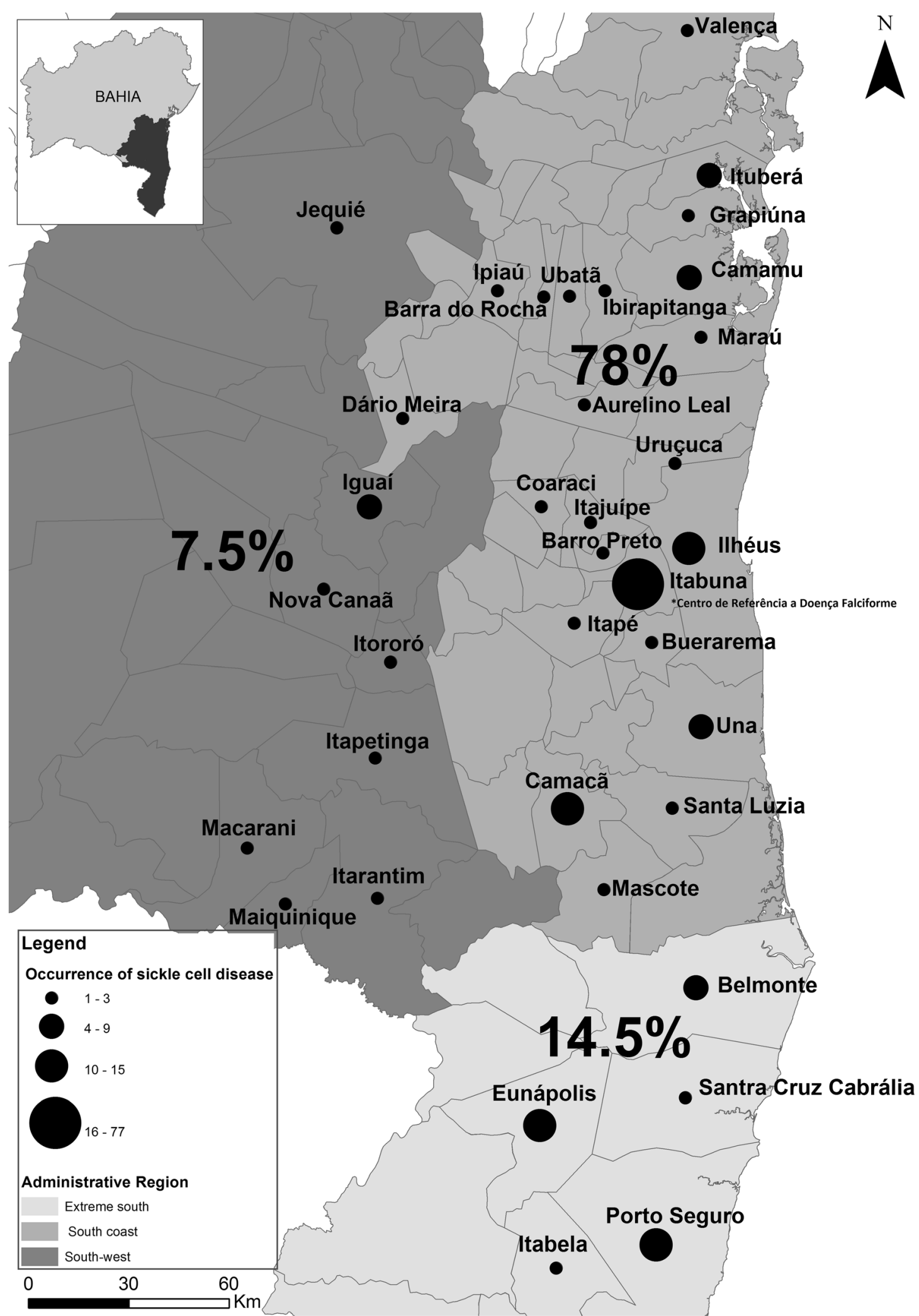

Fig. 1 Distribution of SCD patients on South Coast, Extreme South and Southwest of Bahia 
$5.5 \%(11 / 200)$, and $5.0 \%(10 / 200)$ of the SCD patients respectively.

We found that BEN haplotype (47.9\%; 135/282) was the predominant haplotype in SCA patients, followed by CAR haplotype (45.0\%; 127/282), and atypical haplotype (7.1\%; 20/282). In the HbSC patients, 54.2\% had BEN haplotype (32/59) and $45.8 \%$ had CAR haplotype (27/ $59)$. Regarding the genotype of the $\beta^{S}$ globin gene cluster haplotypes among the SCA patients, 41.2\% (58/141) had BEN/CAR genotype, followed by CAR/CAR genotype (22.7\%; 32/141) and BEN/BEN genotype (24.8\%; 35/141). Among the SCA patients, we found that $5.0 \%$ had BEN/ Atypical genotype (7/141), 3.5\% had CAR/Atypical genotype (5/141), and $2.8 \%$ the atypical genotype (4/141). When we analyzed the $\beta^{C}$ globin gene cluster haplotypes associated to the HbSC, we found that 5.1\% (3/59) had the BEN II genotype, 35.6\% (21/59) had the CAR I genotype, $47.4 \%(28 / 59)$ had the BEN I genotype, $8.5 \%(5 / 59)$ had the CAR III genotype, $1.7 \%(1 / 59)$ had the CAR II genotype, and $1.7 \%(1 / 59)$ had the BEN III genotype (Table 2). The haplotypes are known to modulate $\mathrm{HbF}$ levels, thus, we analyzed 99 patients with SCA and 52 patients with HbSC who had no history of HU therapy and absence of the CAR haplotype lead to elevated $\mathrm{HbF}$ levels (Table 3).

We found that 168 patients had the wild type of the $\alpha$ genotype and that 32 patients had the deletion $\left(-\alpha^{3.7 \mathrm{~Kb}}\right.$ thal). In this group, we observed 4 patients with the homozygous genotype $(-\alpha /-\alpha)$ and 28 patients with the heterozygous genotype $(-\alpha / \alpha)$ (Table 2$)$. When we evaluated 98 patients with SCA and 52 patients with $\mathrm{HbSC}$ who had no history of HU therapy, we have found that hemoglobin and hematocrit concentrations were high and that mean cell volume (MCV) and mean corpuscular hemoglobin $(\mathrm{MCH})$ were low in the presence of the $\alpha^{3.7 K b}$-thal in both SCD genotypes (Table 3).

Among the biomarkers of hemolysis, the red blood cell (RBC) count $(p<0.001)$, hemoglobin $(\mathrm{p}<0.001)$ and hematocrit concentrations $(\mathrm{p}<0.001)$ were low, and MCV ( $\mathrm{p}<0.001), \mathrm{MCH}(\mathrm{p}<0.001)$ concentration and red blood cell distribution width (RDW) $(\mathrm{p}<0.001)$ were high in SCA patients (Table 4). Additionally, in the same group, we found that the levels of total $(\mathrm{p}<0.001)$, direct $(\mathrm{p}<0.001)$ and indirect $(\mathrm{p}<0.001)$ bilirubin, lactate dehydrogenase (LDH) $(p<0.001)$, NOm $(p=0.047)$ and reticulocyte count $(\mathrm{p}<0.001)$ were high (Table 3$)$. We also found that the total white blood cell (WBC) $(\mathrm{p}<0.001)$, eosinophil $(p=0.007)$, lymphocyte $(\mathrm{p}<0.001)$ and monocyte $(p=0.003)$ counts were high in SCA patients (Table 4). The platelet count was increased in SCA patients $(\mathrm{p}<0.001)$. Conversely, we observed low levels of total cholesterol $(p=0.012)$ and high-density lipoprotein cholesterol (HDL-C) $(\mathrm{p}<0.001)$ in these patients (Table 4).

We analyzed the distribution of clinical events in the different SCD genotypes (SCA and $\mathrm{HbSC}$ ) with no history of HU therapy, and we found that hospitalization was strongly associated with the SCA genotype (91.8\%; 90/98) $(p=0.001)$ (Table 5).

With regard to the use of prophylactic penicillin, we identified that $87.5 \%(70 / 80)$ of SCD pediatric patients received prophylactic penicillin therapy. Following the use of prophylactic penicillin therapy, 92.5\% (185/200) of SCD patients in all age groups reported the use of folic acid everyday $(p=0.046)$. HU therapy was used by $25.0 \%(50 / 200)$ of SCD patients all older than 6 years and was more frequently used in patients aged 11 to 31 years $(\mathrm{p}<0.001)$.

\section{Discussion}

The present study analyzed the laboratory, genetic, clinical and demographic characteristics of 200 SCD patients who were followed at the Reference Center living in the south of Bahia in the northeast of Brazil.

We observed low educational level in patients with SCD, which is in accordance with findings from studies

Table 2 Distribution of the genotypes and alleles of the $\beta^{5}$ globin haplotype and $-a^{3.7 \mathrm{~Kb}}$-thalassemia in SCD

\begin{tabular}{|c|c|c|c|c|c|c|c|}
\hline \multicolumn{4}{|c|}{$\beta^{S}$ globin Genotype } & \multicolumn{4}{|c|}{$-\mathrm{a}^{3.7 \mathrm{~Kb}}$-Thalassemia Genotype } \\
\hline $\mathrm{HbSC}$ & $\%(N=59)$ & SCA & $\%(N=141)$ & $\mathrm{HbSC}$ & $\%(N=59)$ & SCA & $\%(N=141)$ \\
\hline BEN II & $5.1(3)$ & BEN/BEN & $24.8(35)$ & Absence & $84.7(50)$ & Absence & 83.7 (118) \\
\hline CAR I & $35.6(21)$ & BEN/CAR & $41.2(58)$ & Heterozygous & $13.6(8)$ & Heterozygous & $14.2(20)$ \\
\hline BEN I & $47.4(28)$ & CAR/CAR & $22.7(32)$ & Homozygous & $1.7(1)$ & Homozygous & $2.1(3)$ \\
\hline CAR III & $8.5(5)$ & BEN/Atypical & $5.0(7)$ & & & & \\
\hline CAR ॥ & $1.7(1)$ & CAR/Atypical & $3.5(5)$ & & & & \\
\hline BEN III & $1.7(1)$ & Atypical & $2.8(4)$ & & & & \\
\hline \multicolumn{2}{|c|}{$\beta^{S}$ globin Haplotype in HbSC } & \multicolumn{2}{|c|}{$\beta^{S}$ globin Haplotype in SCA } & \multicolumn{4}{|c|}{ Frequency of $-a^{3.7 \mathrm{~Kb}}$-Thalassemia chromosome in SCD } \\
\hline BEN & $54.2(32 / 59)$ & BEN & $47.9(135 / 282)$ & \multicolumn{4}{|c|}{ Presence 0.09 (36/400) } \\
\hline \multirow[t]{2}{*}{ CAR } & $45.8(27 / 59)$ & CAR & $45.0(127 / 282)$ & & & & \\
\hline & & Atypical & $7.1(20 / 282)$ & & & & \\
\hline
\end{tabular}


Table 3 Distribution of the median (25th - 75th) hematological data among the $\beta^{S}$ globin haplotypes and $-a^{3.7 k b}$-thalassemia

\begin{tabular}{|c|c|c|c|c|c|c|c|}
\hline \multicolumn{4}{|c|}{$\beta^{S}$ globin Haplotype } & \multicolumn{4}{|c|}{$-\mathrm{a}^{3.7 \mathrm{~Kb}}-$ Thalassemia } \\
\hline \multicolumn{2}{|l|}{$\begin{array}{l}\mathrm{HbSC} \\
(N=52)\end{array}$} & \multicolumn{2}{|l|}{$\begin{array}{l}\text { SCA } \\
(N=99)\end{array}$} & \multicolumn{2}{|l|}{$\begin{array}{l}\mathrm{HbSC} \\
(\mathrm{N}=52)\end{array}$} & \multicolumn{2}{|l|}{$\begin{array}{l}\text { SCA } \\
(N=99)\end{array}$} \\
\hline $\begin{array}{l}\text { Median } \\
\text { (25th - 75th) }\end{array}$ & $\begin{array}{l}\text { Median } \\
\text { (25th - 75th) }\end{array}$ & $\begin{array}{l}\text { Median } \\
(25 \text { th }-75 \text { th })\end{array}$ & $\begin{array}{l}\text { Median } \\
\text { (25th - 75th) }\end{array}$ & $\begin{array}{l}\text { Median } \\
(25 \text { th }-75 \text { th })\end{array}$ & $\begin{array}{l}\text { Median } \\
\text { (25th - 75th) }\end{array}$ & $\begin{array}{l}\text { Median } \\
(25 \text { th }-75 \text { th) }\end{array}$ & $\begin{array}{l}\text { Median } \\
(25 \text { th }-75 \text { th })\end{array}$ \\
\hline $\begin{array}{l}\text { Absence CAR } \\
N=26\end{array}$ & $\begin{array}{l}\text { Presence CAR } \\
N=26\end{array}$ & $\begin{array}{l}\text { Absence CAR } \\
N=29\end{array}$ & $\begin{array}{l}\text { Presence CAR } \\
N=70\end{array}$ & $\begin{array}{l}\text { Absence }-a^{3.7 \mathrm{~kb}} \\
N=43\end{array}$ & $\begin{array}{l}\text { Presence }-a^{3.7 k b} \\
N=9\end{array}$ & $\begin{array}{l}\text { Absence }-a^{3.7 k b} \\
N=85\end{array}$ & $\begin{array}{l}\text { Presence }-a^{3.7 k b} \\
N=14\end{array}$ \\
\hline $\mathrm{HbS}$ & & $\mathrm{HbS}$ & & $\mathrm{Hb}$ & & $\mathrm{Hb}$ & \\
\hline $50.0(48.1-51.4)$ & $50.6(49.5-51.6)$ & $83.0(76.0-88.3)$ & $88.3(83.5-91.7)$ & $10.8(10.1-11.6)$ & $10.9(9.9-12.4)$ & $7.6(7.1-8.3)$ & $8.2(7.3-8.8)$ \\
\hline$p=0.301$ & & $p=0.004$ & & $p=0.735$ & & $p=0.427$ & \\
\hline $\mathrm{HbF}$ & & $\mathrm{HbF}$ & & $\mathrm{Ht}$ & & $\mathrm{Ht}$ & \\
\hline $1.9(0.8-4.5)$ & $1.3(0.7-3.2)$ & $12.9(7.5-18.3)$ & $7.7(4.1-11.5)$ & $30.7(28.7-32.5)$ & $31.7(28.0-34.1)$ & $21.7(19.9-24.1)$ & $23.8(21.4-25.5)$ \\
\hline \multirow[t]{7}{*}{$p=0.181$} & & $p=0.005$ & & $p=0.961$ & & $p=0.252$ & \\
\hline & & & & MCV & & MCV & \\
\hline & & & & $76.1(71.5-80.1)$ & $71.6(67.3-72.4)$ & $88.0(83.6-93.2)$ & $80.3(76.3-83.1)$ \\
\hline & & & & $p=0.018$ & & $p<0.001$ & \\
\hline & & & & $\mathrm{MCH}$ & & $\mathrm{MCH}$ & \\
\hline & & & & $27.2(24.6-28.8)$ & $25.0(23.4-26.5)$ & $30.8(28.8-32.7)$ & $27.7(25.7-29.0)$ \\
\hline & & & & $p=0.071$ & & $p<0.001$ & \\
\hline
\end{tabular}

$\mathrm{Hb}$ hemoglobin, $\mathrm{Ht}$ hematocrit, $\mathrm{MCV}$ mean cell volume, $\mathrm{MCH}$ mean corpuscular hemoglobin. Bold values indicate significance at $\mathrm{p}<0.05 ; \mathrm{p}$-value obtained using Mann-Whitney

in the United States and other Brazilian regions [20, 21]. Another study observed that sociodemographic characteristics had no influence on the development of SCD complications; however, age, low socioeconomic class and education level were associated with anemic crisis in SCD [22, 23].

Among our patients $38.0 \%$ were diagnosed younger than 6 months of age, and 25.0\% were diagnosed between 7 months and 4 years old, which is consistent with a delayed diagnosis. Newborn screening for SCD started in 2001 in Brazil when the National Newborn Screening Program (PNTN)/Guthrie test was founded to test for hemoglobinopathies [24], establishing the important early diagnosis of SCD. Newborn screening for hemoglobinopathies resulted in a reduction of mortality and clinical complications in SCD patients in Brazil, due to the therapeutic and clinical monitoring of the child since the birth [24].

The evaluation of the geographic distribution of the SCD patients included in our study showed high occurrence of SCD patients on the south coast of Bahia, additionally, the majority of the patients were from the city of Itabuna. Itabuna was initially settled in 1867 by cowboys from Sergipe, when they started to immigrate to Vitória da Conquista [25]. Sergipean immigrants, from a state close to Bahia, initiated holdings on the Cachoeira River banks during the same period that the Jesuits provided a catechesis to the Pataxó, Guerren and Camacã natives on farms [25]. African derived people coming from the Sergipe and Bahia backlands in 1850 were attracted to the wealth of the region and the possibility of working on the cocoa farms [25]. In addition, slaves originated from different African tribes and African regions were brought from South Africa to the port of Ilhéus during the slave trade period.

Interestingly, some of the historical aspects suggest the possibility of greater dispersion of the $\beta^{S}$ allele in Itabuna. The predominant haplotype in SCA patients was BEN/CAR, as well as in HbSC patients was the haplotype BEN I followed by CAR I. According to the literature, in 1678-1814, approximately 39 of the 1770 ships that exported tobacco from Bahia went to Congo and Angola, where they captured Africans for slave labor, which represents the genetic contribution from the central Atlantic region of Africa [26]. After 1815, Bahia was the only Brazilian state that restricted slave traffic through Ecuador, which explains the association between the genotypic frequencies in Bahia and Western Africa, principally the Benin region [27]. We found high levels of $\mathrm{HbF}$ and low levels of $\mathrm{HbS}$ in patients with the BEN haplotype. Most of the patients with the CAR haplotype had low HbF levels (below 5\% of the total $\mathrm{HbF}$ ), whereas carriers of the BEN haplotype had intermediate HbF levels (between 5 and 15\%) and this is in agreement with a previous study [28].

In Brazil, the prevalence of $-\alpha^{3.7 \mathrm{~Kb}}$-thal is associated with different ethnic groups that constitute the population [29]. We observed a high prevalence of $-\alpha^{3.7 \mathrm{~Kb}}$-thal 
Table 4 Comparison of the laboratory data between SCA and HbSC patients

\begin{tabular}{|c|c|c|c|}
\hline Laboratory value & $\begin{array}{l}\text { SCA }(N=98) \\
\text { Median }(25 \text { th }-75 \text { th })\end{array}$ & $\begin{array}{l}\text { HbSC }(\mathrm{N}=52) \\
\text { Median }(25 \text { th }-75 \text { th })\end{array}$ & $\mathrm{p}$ value \\
\hline \multicolumn{4}{|l|}{ Hemolysis } \\
\hline $\mathrm{RBC}, \times 10^{12} / \mathrm{L}$ & $2.60(2.30-2.80)$ & $4.15(3.80-4.50)$ & $<0.001$ \\
\hline Hemoglobin, g/dL & $7.60(7.15-8.50)$ & $10.90(10.12-11.82)$ & $<0.001$ \\
\hline Hematocrit, \% & $21.80(20.15-24.47)$ & $30.80(28.72-32.50)$ & $<0.001$ \\
\hline$M C V, f L$ & 86.05 (81.37-91.10) & 74.40 (70.80-79.72) & $<0.001$ \\
\hline $\mathrm{MCH}, \mathrm{fL}$ & $30.15(27.87-32.25)$ & $26.60(24.60-28.67)$ & $<0.001$ \\
\hline RDW, fL & $24.80(21.60-27.20)$ & 18.65 (17.62-19.57) & $<0.001$ \\
\hline Total bilirubin, mg/dL & $2.55(1.67-3.72)$ & $1.20(0.80-1.67)$ & $<0.001$ \\
\hline Direct bilirubin, mg/dL & $0.45(0.30-0.60)$ & $0.30(0.20-0.40)$ & $<0.001$ \\
\hline Indirect bilirubin, mg/dL & $2.20(1.20-3.12)$ & $0.90(0.52-1.27)$ & $<0.001$ \\
\hline $\mathrm{LDH}, \mathrm{U} / \mathrm{L}$ & 1094.00 (785.50-1684.50) & $481.50(381.75-567.25)$ & $<0.001$ \\
\hline \multicolumn{4}{|l|}{ Reticulocyte } \\
\hline Reticulocyte count & $5.40(4.20-8.20)$ & $3.65(2.62-4.37)$ & $<0.001$ \\
\hline \multicolumn{4}{|l|}{ NO metabolites } \\
\hline NOm, $\mu \mathrm{M}$ & $35.62(28.02-47.50)$ & 31.34 (23.19-40.80) & 0.047 \\
\hline \multicolumn{4}{|l|}{ Leukocytes } \\
\hline $\mathrm{WBC}, \times 10^{9} / \mathrm{L}$ & $13.80(11.17-16.10)$ & $10.45(7.22-12.90)$ & $<0.001$ \\
\hline Segment count, $\times 10^{9} / \mathrm{L}$ & $5778.00(4275.25-7203.50)$ & $5182.00(3498.50-6717.00)$ & 0.080 \\
\hline Eosinophil count, $\times 10^{9} / \mathrm{L}$ & $695.50(281.50-1774.75)$ & $421.50(216.50-895.25)$ & 0.007 \\
\hline Lymphocyte count, $\times 10^{9} / \mathrm{L}$ & $5535.00(4335.00-7156.50)$ & $3356.50(2492.00-4704.75)$ & $<0.001$ \\
\hline Monocyte count, $\times 10^{9} / \mathrm{L}$ & $349.50(219.00-670.75)$ & $257.00(144.50-402.75)$ & 0.003 \\
\hline \multicolumn{4}{|l|}{ Platelets } \\
\hline Platelet count, $\times 10^{3} / \mathrm{mL}$ & $441.50(365.25-547.00)$ & $267.00(189.50-389.00)$ & $<0.001$ \\
\hline$M P V, f L$ & $9.50(8.80-10.40)$ & $9.70(9.30-10.40)$ & 0.314 \\
\hline \multicolumn{4}{|l|}{ Lipid metabolism } \\
\hline Total Cholesterol, mg/dL & $122.00(97.75-146.75)$ & $133.50(110.25-166.75)$ & 0.012 \\
\hline $\mathrm{HDL}-\mathrm{C}, \mathrm{mg} / \mathrm{dL}$ & $32.00(27.00-38.00)$ & $37.00(33.00-44.75)$ & $<0.001$ \\
\hline $\mathrm{LDL}-\mathrm{C}, \mathrm{mg} / \mathrm{dL}$ & $67.00(41.75-88.25)$ & 73.00 (57.00-109.75) & 0.071 \\
\hline $\mathrm{VLDL}-\mathrm{C}, \mathrm{mg} / \mathrm{dL}$ & $22.00(16.75-31.25)$ & $21.00(14.00-27.75)$ & 0.178 \\
\hline Triglycerides, mg/dL & $110.00(82.75-156.50)$ & $103.50(68.50-138.50)$ & 0.175 \\
\hline
\end{tabular}

$R B C$ red blood cells, $M C V$ mean cell volume, $M C H$ mean corpuscular hemoglobin, RDW red cell distribution width, $L D H$ lactate dehydrogenase, NOm: nitric oxide metabolites, WBC white blood cell, MPV mean platelet volume, $H D L-C$ high-density lipoprotein cholesterol, $L D L-C$ low-density lipoprotein cholesterol, VLDL-C very low-density lipoprotein cholesterol; Bold values indicate significance at $p<0.05 ; p$-value obtained using Mann-Whitney

deletion in the studied population. It is estimated that in Brazil, the overall frequency of the $\alpha$-thalassemia trait is between $1 \%$ and $3 \%$ [30]. According to our results, the association with co-inheritance of $\alpha^{3.7 \mathrm{~Kb}}$-thal deletion lead to increased hemoglobin levels, despite the microcytosis, hypochromia and increased hematocrit levels. The literature reports that the homozygous and heterozygous states of $-\alpha^{3.7 \mathrm{~Kb}}$-thal, are characterized by mild anemia, hypochromia and microcytosis. However, increased hematocrit levels are observed, which contribute to enhance blood viscosity, increase vaso-occlusion and the occurrence of clinical events [7, 31].
Several studies have demonstrated the pathophysiological mechanisms underlying SCA and $\mathrm{HbSC}$. We observed that SCA patients had a more prominent hemolytic pattern compared to $\mathrm{HbSC}$ patients who presented a lower RBC count and hemoglobin concentration, and increased LDH levels. This is in agreement with previous studies that described that in $\mathrm{HbSC}$ patients the $\mathrm{HbC}$ presence induces the $\mathrm{HbS}$ polymerization; however, it occur in a reduced degree when compared to SCA patients. Thus, HbSC patients exhibits a less severe hemolytic anemia $[2,32]$.

We identified increased reticulocytes count in SCA patients in response to hemolysis. This is related to anemic 
Table 5 Clinical characterization of SCA and HbSC patients

\begin{tabular}{llll}
\hline Clinical characterization & SCA & HbSC & p value \\
& $\mathrm{N}=98$ & $\mathrm{~N}=52$ & \\
\hline Hospitalization & $90 / 98(91.8 \%)$ & $36 / 52(69.2 \%)$ & $\mathbf{0 . 0 0 1}$ \\
Pneumonia & $38 / 98(38.8 \%)$ & $22 / 52(42.3 \%)$ & 0.728 \\
Splenomegaly & $40 / 98(40.8 \%)$ & $18 / 52(34.6 \%)$ & 0.486 \\
Asthma & $6 / 98(6.1 \%)$ & $3 / 52(5.8 \%)$ & 1.000 \\
Pain crises & $83 / 98(84.7 \%)$ & $41 / 52(78.8 \%)$ & 0.374 \\
Infection & $36 / 98(36.7 \%)$ & $18 / 52(34.6 \%)$ & 0.859 \\
Priapism & $10 / 50(20.0 \%)$ & $5 / 22(22.7 \%)$ & 0.764 \\
Vaso-occlusion & $89 / 98(90.8 \%)$ & $42 / 52(80.8 \%)$ & 0.119 \\
Retinopathy & $3 / 98(3.0 \%)$ & $4 / 52(7.7 \%)$ & 0.236 \\
Cholelithiasis & $17 / 98(17.3 \%)$ & $4 / 52(7.7 \%)$ & 0.139 \\
\hline
\end{tabular}

Comparison of clinical events among the SCA and HbSC genotypes calculated using the Fisher's exact test. Bold values indicate significance at $p<0.05$

stress that promotes the release of immature RBCs from the bone marrow, which consequently increases reticulocytes count on peripheral blood [33]. We observed a slight decrease in NOm in HbSC patients. The lysis of erythrocytes promotes the release of free $\mathrm{Hb}$ in the plasma, which promotes inflammatory and oxidative effects that contribute to endothelial dysfunction [12, 34]. Due to hemolysis, heme, reactive oxygen species (ROS) and arginase are released into the bloodstream, increasing oxidative stress and decreasing NOm levels $[35,36]$.

Patients with HbSC had lower leukocyte count than SCA patients. This result is consistent with previous findings that identify the same association [37]. Moreover, SCA patients had higher platelet counts; however, the mean platelet volume (MPV) was high in both the genotypes. An increase in platelet activation has been found in SCD patients during vaso-occlusive events. Platelets regulate hemostasis, but they are also responsible for inducing inflammation [38].

The analysis of the lipid profile in SCD patients have shown lower HDL-C levels, as well as values below the reference value, which represents an important cardiovascular risk factor [39-41]. Hypertriglyceridemia and increased very low-density lipoprotein cholesterol (VLDL-C) were observed in SCA patients in this study, although these results were not statistically significant. According to previous reports, SCD individuals have decreased lipid plasma levels during hemolytic stress and compared with normal individuals [42].

Clinical manifestations are considered a limiting factor that may influence patient mortality; these include pain crisis, VOE and the coexistence of comorbidities, such as legs ulcers, infection, cholelithiasis, splenomegaly, retinopathy, vascular necrosis, and neurological disorders, which have a negative effect on the cognitive development of these patients $[11,16]$. As demonstrated by our results, we found increased hospitalizations in SCA patients, once this is the most severe genotype of SCD characterized by a higher incidence of clinical complications and hospitalizations than HbSC [16].

We found that a high percentage of patients used oral prophylactic penicillin, including Benzathine, which was administered in patients prior to age 7 years. The prophylactic use of penicillin significantly reduces the risk of sepsis and death due to pneumococcal infection [43]. Another prescribed drug, folic acid, is used in cases of increased activity secondary to chronic hemolysis that results in high RBC destruction and leads to a deficit in folic acid $[43,44]$. Our data showed daily high adherence to folic acid use in all age groups [45].

\section{Conclusion}

Our data highlight the differences between subphenotypes among SCA and HbSC patients, based on laboratory characterization, genetic profiles and clinical manifestations of both genotypes. The results of our analyses emphasize the need for specialized care services for SCA and HbSC patients, particularly because of their heterogeneous genetic, clinical and pathophysiological backgrounds, and indicate the need for public health policies that significantly improve the health of these patients.

\section{Abbreviations}

ACS: Acute chest syndrome; BEN: Benin; CAM: Arab-Indian, and Cameroon; CAR: Central African Republic; HbC: Hemoglobin C; HbF: Fetal hemoglobin; HbS: Hemoglobin S; HbSC: Hemoglobin SC disease; HDL-C: High-density lipoprotein cholesterol; HU: Hydroxyurea; LDH: Lactate dehydrogenase; MCH: Mean corpuscular hemoglobin; MCV: Mean cell volume; MPV: Mean platelet volume; NOm: Nitric oxide metabolites; PCR: Reaction polimerase chain; RBC: Red blood cell; RDW: Red blood cell distribution width; RFLP: Restriction fragment length polymorphism; ROS: Reactive oxygen species; SCA: Sickle cell anemia; SCD: Sickle cell disease; SEN: Senegal; VLDLC: Very low-density lipoprotein cholesterol; VOE: Vaso occlusion events; WBC: White blood cell; - $a^{3.7 k b}$-thal: $-a^{3.7 k b}$-thalassemia

\section{Acknowledgements}

Not applicable.

\section{Funding}

No funding was received.

\section{Availability of data and materials}

The datasets supporting the conclusions of this article are included in the article.

\begin{abstract}
Authors' contributions
MMA, MSG and BAVC, performed conception and design of the study, acquisition of data, analysis and interpretation of data. RPS, CCG and JRDF drafting the article or revising it critically for important intellectual content. TCCF, FIN, RQS and BLAC assisted and performed the blood collection of the patients. CVBF and SSP helped perform the experiments, the hematological, biochemical and molecular analysis. SSS helped review the medical records and perform the statistical analyses. All authors read and approved the final manuscript.
\end{abstract}

Ethics approval and consent to participate

The study received approval from the institutional review board of Instituto Gonçalo Moniz at the Fundação Oswaldo Cruz (IGM-FIOCRUZ - Bahia Brazil) (CAAE 08452913.9.0000.0040) and the informed consent was obtained 
from all the adults participants and children with consent of parents or guardians.

\section{Consent for publication \\ Not applicable.}

\section{Competing interests}

The authors declare that they have no competing interests.

\section{Publisher's Note}

Springer Nature remains neutral with regard to jurisdictional claims in published maps and institutional affiliations.

\section{Author details}

'Laboratório de Hematologia e Genética Computacional, Instituto Gonçalo Moniz - IGM, Fundação Oswaldo Cruz (Fiocruz), Rua Waldemar Falcão, 121, Candeal, Salvador, Bahia CEP 40296-710, Brazil. Universidade Federal da Bahia (UFBA), Salvador, Bahia, Brazil. ${ }^{3}$ Centro de Referência a Doença Falciforme, Itabuna, Bahia, Brazil. ${ }^{4}$ Universidade Estadual de Santa Cruz (UESC), Ilhéus, Bahia, Brazil. 'Universidade Estadual da Bahia (UNEB), Salvador, Bahia, Brazil.

Received: 23 December 2016 Accepted: 5 September 2017

\section{Published online: 15 September 2017}

\section{References}

1. WHO/AFRO. The health of the people: what works - the African Regional Health Report. Public health - organization and administration. 2014.

2. Grosse SD, Odame I, Atrash HK, Amendah DD, Piel FB, Williams TN. Sickle cell disease in Africa: a neglected cause of early childhood mortality. Am J Prev Med. 2011;41(6 Suppl 4):S398-405.

3. Steinberg MH. Genetic etiologies for phenotypic diversity in sickle cell anemia. ScientificWorldJournal. 2009;9:46-67.

4. Rees DC, Gibson JS. Biomarkers in sickle cell disease. Br J Haematol. 2012; 156(4):433-45.

5. Steinberg MH, Coleman MB, Adams JG, Rosenstock W. Interaction between HBS-beta-o-thalassemia and alpha-thalassemia. Am J Med Sci. 1984;288(5): 195-9.

6. Steinberg MH, Sebastiani P. Genetic modifiers of sickle cell disease. Am J Hematol. 2012;87(8):795-803.

7. Adorno EV, Couto FD, Moura Neto JP, Menezes JF, Rego M, Reis MG, et al. Hemoglobinopathies in newborns from Salvador, Bahia, Northeast Brazil. Cadernos de saude publica. 2005;21(1):292-8.

8. Charache S. Fetal hemoglobin, sickling, and sickle cell disease. Adv Pediatr. 1990;37:1-31.

9. Nagel RL, Fabry ME. Sickle cell anemia as a multigenetic disease: new insights into the mechanism of painful crisis. Prog Clin Biol Res. 1984;165: 93-102

10. Goncalves MS, Bomfim GC, Maciel E, Cerqueira I, Lyra I, Zanette A, et al. BetaS-haplotypes in sickle cell anemia patients from Salvador, Bahia, Northeastern Brazil. Brazilian journal of medical and biological research = Revista brasileira de pesquisas medicas e biologicas / Sociedade Brasileira de Biofisica [et al]. 2003;36(10):1283-8.

11. Steinberg $\mathrm{MH}$. Predicting clinical severity in sickle cell anaemia. $\mathrm{Br} \mathrm{J}$ Haematol. 2005;129(4):465-81.

12. Kato GJ, Gladwin MT, Steinberg MH. Deconstructing sickle cell disease: reappraisal of the role of hemolysis in the development of clinical subphenotypes. Blood Rev. 2007;21(1):37-47.

13. Damanhouri GA, Jarullah J, Marouf S, Hindawi SI, Mushtaq G, Kamal MA. Clinical biomarkers in sickle cell disease. Saudi journal of biological sciences. 2015;22(1):24-31.

14. Steinberg $\mathrm{MH}$, Barton F, Castro O, Pegelow CH, Ballas SK, Kutlar A, et al. Effect of hydroxyurea on mortality and morbidity in adult sickle cell anemia: risks and benefits up to 9 years of treatment. JAMA. 2003;289(13):1645-51.

15. Raphael JL, Dietrich CL, Whitmire D, Mahoney DH, Mueller BU, Giardino AP. Healthcare utilization and expenditures for low income children with sickle cell disease. Pediatr Blood Cancer. 2009:52(2):263-7.

16. Pizzo E, Laverty AA, Phekoo KJ, AlJuburi G, Green SA, Bell D, et al. A retrospective analysis of the cost of hospitalizations for sickle cell disease with crisis in England, 2010/11. J Public Health (Oxf). 2015;37(3):529-39.
17. Nims RW, Cook JC, Krishna MC, Christodoulou D, Poore CM, Miles AM, et al. Colorimetric assays for nitric oxide and nitrogen oxide species formed from nitric oxide stock solutions and donor compounds. Methods Enzymol. 1996; 268:93-105.

18. Sutton M, Bouhassira EE, Nagel RL. Polymerase chain reaction amplification applied to the determination of beta-like globin gene cluster haplotypes. Am J Hematol. 1989;32(1):66-9.

19. Chong SS, Boehm CD, Higgs DR, Cutting GR. Single-tube multiplex-PCR screen for common deletional determinants of alpha-thalassemia. Blood. 2000;95(1):360-2.

20. Carroll PC, Haywood C Jr, Hoot MR, Lanzkron S. A preliminary study of psychiatric, familial, and medical characteristics of high-utilizing sickle cell disease patients. Clin J Pain. 2013;29(4):317-23.

21. Loureiro MM, Rozenfeld S. Epidemiology of sickle cell disease hospital admissions in Brazil. Rev Saude Publica. 2005;39(6):943-9.

22. Adegoke SA, Adeodu OO, Adekile AD. Sickle cell disease clinical phenotypes in children from south-western. Nigeria Niger J Clin Pract. 2015:18(1):95-101.

23. Ballas SK, Kesen MR, Goldberg MF, Lutty GA, Dampier C, Osunkwo I, et al. Beyond the definitions of the phenotypic complications of sickle cell disease: an update on management. ScientificWorldJournal. 2012;2012:949535.

24. Serjeant GR. Screening for sickle-cell disease in Brazil. Lancet (London, England). 2000;356(9224):168-9.

25. Aleluia MM, Santiago RP, da Guarda CC, Fonseca TCC, Neves Fl, Quinto RS, et al. Genetic Modulation of Fetal Hemoglobin in Hydroxyurea-Treated Sickle Cell Anemia. American journal of hematology. 2017:n/a-n/a.

26. Verger. Flux et Reflux de la Traite des Nègres Entre le Golfe de Benin et Bahia de Todos os Santos. Mouton Press, Paris, France. 1968.

27. Florentino M. Em Costas Negras. Companhia das Letras Press. 1997.

28. Powars DR. Beta s-gene-cluster haplotypes in sickle cell anemia. Clinical and hematologic features. Hematol Oncol Clin North Am. 1991;5(3):475-93.

29. Harteveld CL, Higgs DR. Alpha-thalassaemia. Orphanet journal of rare diseases. 2010:5:13.

30. Figueiredo MS, Kerbauy J, Goncalves MS, Arruda VR, Saad ST, Sonati MF, et al. Effect of alpha-thalassemia and beta-globin gene cluster haplotypes on the hematological and clinical features of sickle-cell anemia in Brazil. Am J Hematol. 1996:53(2):72-6.

31. Lyra IM, Goncalves MS, Braga JA, Gesteira Mde F, Carvalho MH, Saad ST, et al. Clinical, hematological, and molecular characterization of sickle cell anemia pediatric patients from two different cities in Brazil. Cadernos de saude publica. 2005:21(4):1287-90.

32. Kato GJ, Hebbel RP, Steinberg MH, Gladwin MT. Vasculopathy in sickle cell disease: biology, pathophysiology, genetics, translational medicine, and new research directions. Am J Hematol. 2009;84(9):618-25.

33. Discher DE, Ney PA. The reason sickle reticulocytes expose PS. Blood. 2015; 126(15):1737-8.

34. Belanger AM, Keggi C, Kanias T, Gladwin MT, Kim-Shapiro DB. Effects of nitric oxide and its congeners on sickle red blood cell deformability. Transfusion. 2015;55(10):2464-72.

35. Vilas-Boas W, Cerqueira BA, Zanette AM, Reis MG, Barral-Netto M, Goncalves MS. Arginase levels and their association with Th17-related cytokines, soluble adhesion molecules (sICAM-1 and sVCAM-1) and hemolysis markers among steady-state sickle cell anemia patients. Ann Hematol. 2010;89(9):877-82.

36. Dutra FF, Alves LS, Rodrigues D, Fernandez PL, de Oliveira RB, Golenbock DT, et al. Hemolysis-induced lethality involves inflammasome activation by heme. Proc Natl Acad Sci U S A. 2014;111(39):E4110-8.

37. Colella MP, de Paula EV, Machado-Neto JA, Conran N, Annichino-Bizzacchi JM, Costa FF, et al. Elevated hypercoagulability markers in hemoglobin SC disease. Haematologica. 2015;100(4):466-71.

38. Wun T, Paglieroni T, Tablin F, Welborn J, Nelson K, Cheung A. Platelet activation and platelet-erythrocyte aggregates in patients with sickle cel anemia. J Lab Clin Med. 1997;129(5):507-16.

39. Villagra J, Shiva S, Hunter LA, Machado RF, Gladwin MT, Kato GJ. Platelet activation in patients with sickle disease, hemolysis-associated pulmonary hypertension, and nitric oxide scavenging by cell-free hemoglobin. Blood. 2007;110(6):2166-72

40. Executive Summary of The Third Report of The National Cholesterol Education Program (NCEP) Expert Panel on Detection, Evaluation, And Treatment of High Blood Cholesterol In Adults (Adult Treatment Panel III). Jama. 2001;285(19):2486-97.

41. Movva R, Rader DJ. Laboratory assessment of HDL heterogeneity and function. Clin Chem. 2008;54(5):788-800. 
42. Gaston MH, Verter Jl, Woods G, Pegelow C, Kelleher J, Presbury G, et al. Prophylaxis with oral penicillin in children with sickle cell anemia. A randomized trial. N Engl J Med. 1986;314(25):1593-9.

43. Dixit R, Nettem S, Madan SS, Soe HH, Abas AB, Vance LD, et al. Folate supplementation in people with sickle cell disease. Cochrane Database Syst Rev. 2016;2:Cd011130.

44. Martyres DJ, Vijenthira A, Barrowman N, Harris-Janz S, Chretien C, Klaassen RJ. Nutrient insufficiencies/deficiencies in children with sickle cell disease and its association with increased disease severity. Pediatr Blood Cancer. 2016;

45. Nwenyi E, Leafman J, Mathieson K, Ezeobah N. Differences in quality of life between pediatric sickle cell patients who used hydroxyurea and those who did not. Int J Health Care Qual Assur. 2014;27(6):468-81.

Submit your next manuscript to BioMed Central and we will help you at every step:

- We accept pre-submission inquiries

- Our selector tool helps you to find the most relevant journal

- We provide round the clock customer support

- Convenient online submission

- Thorough peer review

- Inclusion in PubMed and all major indexing services

- Maximum visibility for your research

Submit your manuscript at www.biomedcentral.com/submit
Biomed Central 